\title{
Continuous Seismic Survey of Bermuda, Part II, Harrington Sound*
}

R.A. GEES and F. MEDIOLI

Department of Geology, Dalhousie University, Halifax, N. S.

Introduction

For remarks concerning the geographic position of the Bermuda Islands, the purpose of this study, and the geophysical methods by which it was carried out, the reader is referred to Gees and Medioli (1970). It should be pointed out however, that in Harrington Sound the apparent subbottom penetration under optimum conditions amounts to only about 200 feet. In Castle Harbour Gees and Medioli (1970) penetrations of up to 500 feet were recorded. This shallow apparent penetration in Harrington Sound is probably related to the presence of extensive peat deposits in the sub-bottom (personal communication A.C. Neumann).

The survey of Harrington Sound consists of 22 traverses having a total length of 16 miles.

Geomorphology

Harrington sound is a shallow marine inland water body of almost trapezohedral shape. The NE-SW axis is about two miles long and the NW-SE axis measures approximately one and one-half miles (Fig. 1). A narrow channel near Flats connects Harrington Sound with the North Lagoon. The hilly country surrounding Harrington Sound reaches elevations of up to 120 feet. The Pleistocene sediments exposed in this vicinity consist of a sequence of marine limestones and eolianites, and are represented by the Walsingham, Belmont, Devonshire, Harrington and Pembroke Formations (Land and Mackenzie, 1969; Neumann, 1965; Gees and Medioli, 1970).

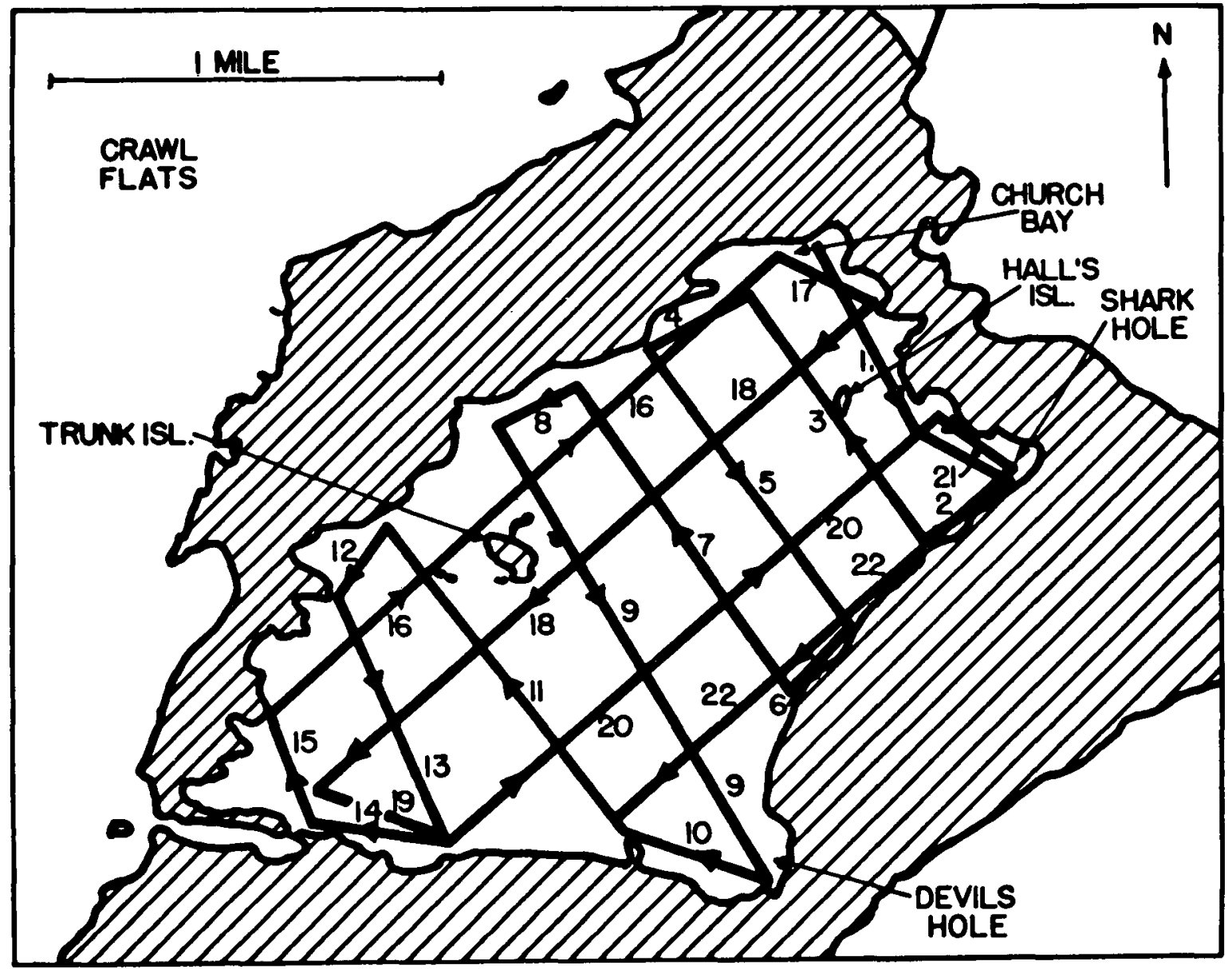

Figure 1. Harrington Sound-Tracks of the Seismic-Survey. 
Only scarce evidence delineating the interface between the volcanics and the sediments was found. In the Devils Hole area, the deepest unit appearing on the seismic records displays a fairly irregular, rather well defined surface. Within this unit or less randomly distributed,Fig. 2, upward-pointing, cone-shaped reflectors are present. It seems reasonable to interpret this lowest unit as basalt, similar to that present in the sub-bottom of Castle Harbour. Superimposed on this lowest unit is a unit believed to consist of a sequence of marine limestones and eolinites. This unit is truncated by a well delineated near horizontal reflector, similar to that in Castle Harbour (Gees and Medioli, 1970). This feature can be traced throughout most of the sub-bottom of Harrington Sound. In Figure 3 a portion of this reflector is depicted. In Shark Hole and Devils Hole the seismic records reveal that the reflector is nearly exposed. However, the relatively thin veneer of Recent and sub-Recent sediments covering these areas cannot be sufficiently resolved on the seismic records. Consequently the apparently nearly outcropping reflector may be covered by these sediments.

Above the horizontal reflector follows a series of sediments, very likely marine limestones and eolianites. As already pointed out the Recent and sub-Recent sediments appear to be fairly thin. They are concentrated mainly in the deeper portions of Harrington Sound. The maximum thickness appears to be in the order to several tens of feet.

\section{Discussion}

Gees and Medioli (1970) delineated the volcanic sub-bottom in the Castle Harbour area and suggested the presence of a caldera-like structure. It is conceivable that a similar volcanic subbottom, such as a caldera, exists in Harrington Sound. If this were the case the present morphology of the Harrington Sound area would more or less reflect the shape of this sub-bottom feature. This hypothesis is based more on the morphological analogies between Castle Harbour and Harrington Sound than on actual information pertaining to the outlines of the volcanic sub-bottom. At this stage of the investigation nothing further can be said concerning this matter.

Within the sediments deposited on top of the volcanics the earlier-mentioned horizontal reflector requires further consideration. A similar feature discovered in the Castle Harbour area (Gees and Medioli, 1970) was interpreted as a peneplain. It appears reasonable to correlate the two features as one large peneplain. This correlation is further supported by unpublished data on the Great Sound and the North Lagoon. The Castle Harbour peneplain was tentatively dated as older than 300,000 years B.P., i.e. post-Walsingham in age. The peneplain apparently developed mainly in the low lying areas of the Walsingham formation. Areas of higher elevation were apparently

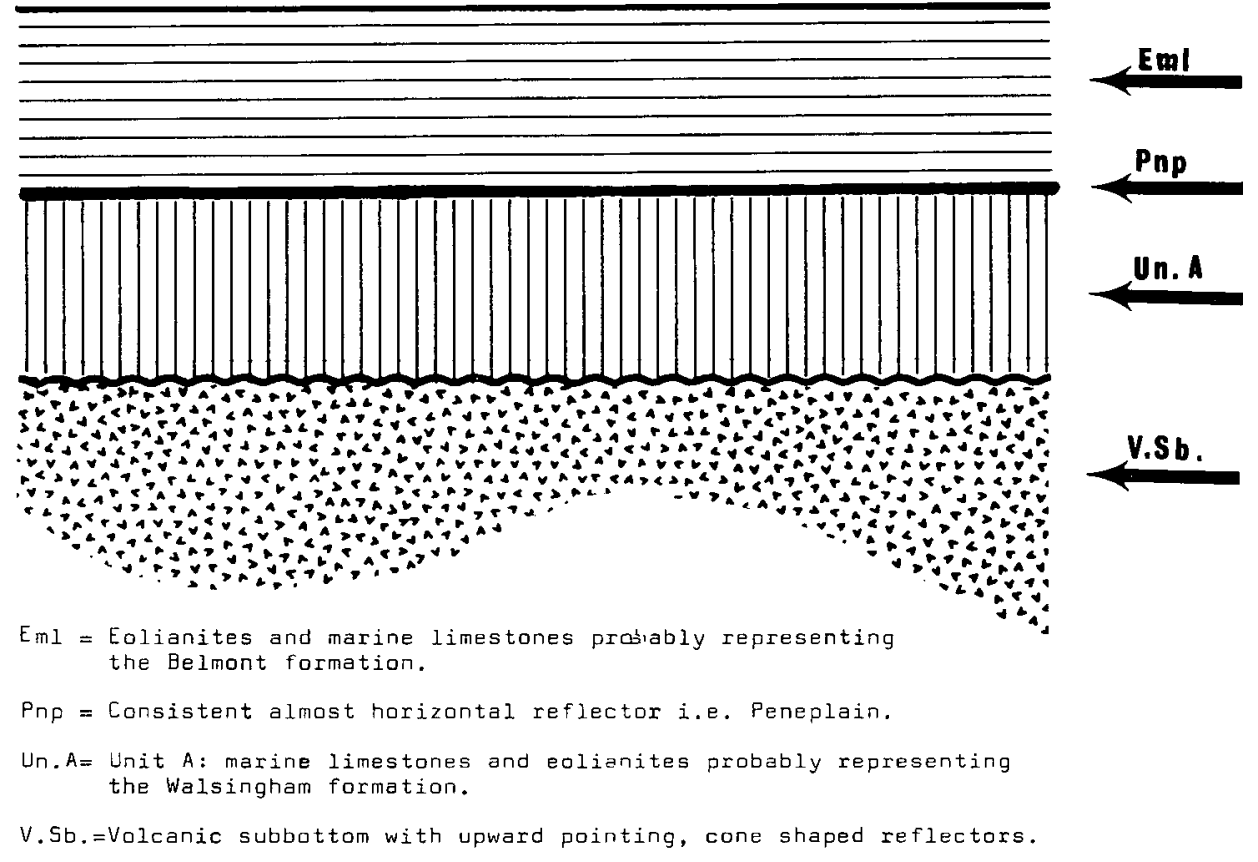

Figure 2. Schematic drawing of geological section in Harrington Sound, Bermuda. 


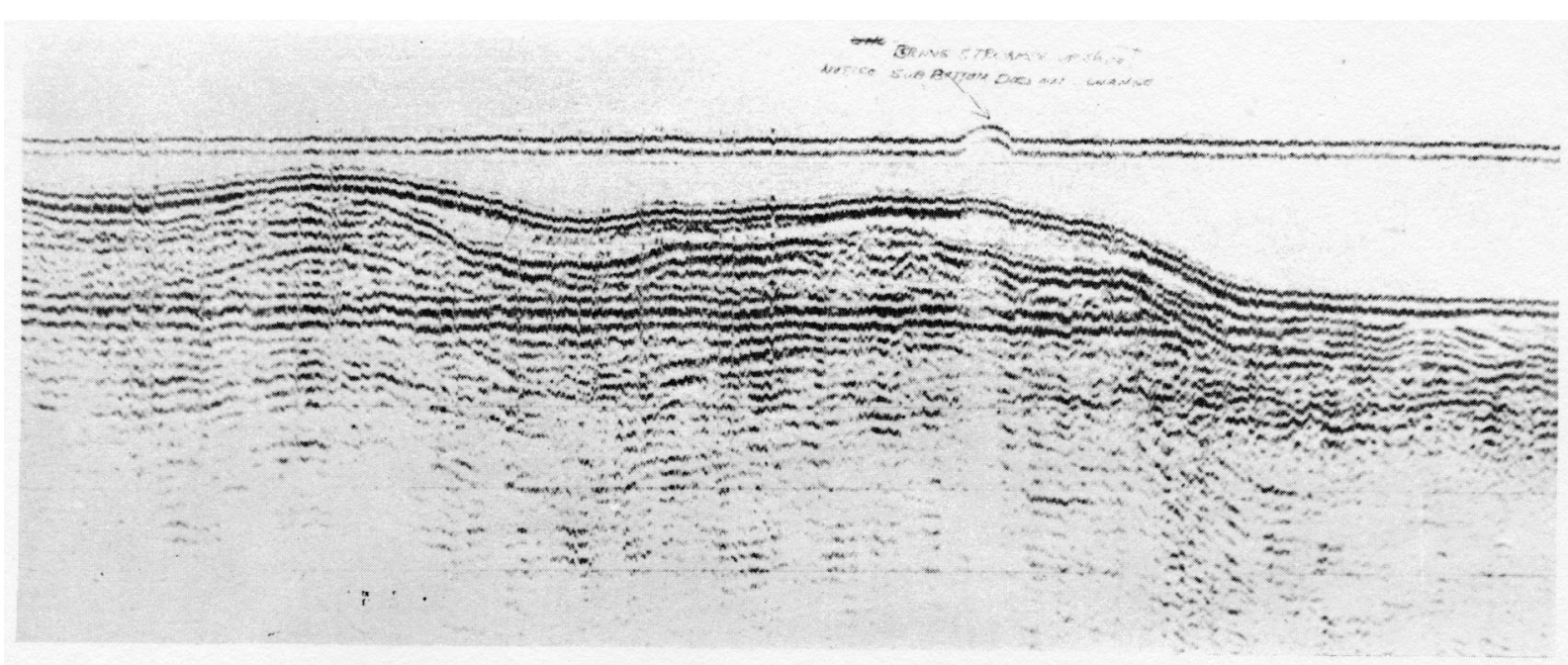

Figure 3. A portion of the peneplain (pnp) near Devils Hole on track 9.

preserved in several locations. If this is correct the ancient (pre-Belmont) morphology of Harrington Sound must have consisted of a low lying horizontal area on which groups of hills having low elevations were superimposed. Some of these hills were arranged in a pattern roughly comparable to today's outline of Harrington Sound. This implies that the geomorphology of Harrington Sound is related to the pre-Belmont relief rather than to an older volcanic caldera as mentioned earlier.

Younger sediments of Belmont age, i.e. a sequence of marine limestones and eolianites, were subsequently deposited on this pre-existing relief (Land, Mackenzie, Gould, 1967). These yonger sediments are represented by a sequence of eolianite and marine limestones representing the Belmont formation.

\section{Conclusions}

The continuous reflection seismic survey of Harrington Sound revealed the following subbottom features: (a) A poorly delineated volcanic sub-bottom. The interface between volcanics and sediments was detected only in isolated areas. (b) A unit probably consisting of marine limestones and eolianites. (c) A clearly delineated peneplain, which is probably the equivalent of the peneplain present in the sub-bottom of Castle Harbour (Gees and Medioli, 1970). (d) Eolianites and marine limestones deposited on the peneplain.

At this stage of the investigation the geomorphology of the Harrington Sound inland marine water body remains an open question. Three possible explanations are suggested: (1) The outlines of Harrington Sound are controlled by the presence of a volcanic sub-bottom forming a caldera-like structure, similar to Castle Haxbour, upon which the Pleistocene sediments were deposited. (2) The morphology of Harrington Sound could be related to an earlier relief of pre-Belmont age. (3) Because of the abundance of karst phenomena in the area, the possibility that Harrington Sound represents a comparatively young, (post-Belmont) large doline, cannot be ruled out completely.

\section{References cited}

GEES, R.A. and MEDIOLI, F., 1970, A continuous seismic survey of the Bermuda Platform, Part I: Castle Harbour. Maritime Sediments, Vol. 6, No. 1, pp. 21-25.

LAND, L.S., MACKENZIE, F.T., and GOULD, S.J., 1967, Pleistocene history of Bermuda. G.S.A. Bull., Vol. 78 . 1969, Field guide to Bermuda Geology (Unpublished).

NEUMANN, A.C., 1965, Processes of recent carbonate sedimentation in Harrington Sound, Bermuda. Bull. Marine Sci., Vol. 15, pp. 987-1035. 